- Traktowaniem poznania jako projekcji apriorycznych kategorii (idei); ,mówi się o przynależnej każdemu człowiekowi od urodzenia zdolności, która umożliwia mu poznawczą orientację w rzeczywistości (tzw. kompetencję poznawczą)" (s. 36);

- podkreśleniem wartości „poznania indywidualnego, poznania konkretu, poznania intuicyjnego” oraz „bezpośredniego kontaktu przedmiotu poznającego z przedmiotem poznania" (s. 37);

- uznaniem przez antypedagogów za „niemiarodajne, upraszczające oraz ingerencyjne" (s. 135) empirycznych metod poznania;

- uznaniem spontaniczności za „wartość poznawczą” (s. 135).

Rozdział czwarty omawianej publikacji poświęcił Autor ocenie postpedagogicznych poglądów. Zastrzeżenie, że nie zawarto w nim skrystalizowanej koncepcji oceniającej, zdecydowanie odbiega od nachalnej, postmodernistycznej indoktrynacji antypedagogiki. Stawiając w nim pytania dotyczące metodologicznych i teoretycznych podstaw antypedagogiki, a także jej zaplecza filozoficznego oraz ideologicznych inspiracji, rozumnej refleksji Czytelnika pozostawiamy odpowiedź, czy z tych zmagań wyszedł zwycięsko.

Marek Marczewski*

\title{
Elżbieta Kościńska, Zachowania ryzykowne seniorów. Uwarunkowania, profilaktyka, Bydgoszcz: Wydawnictwo Uniwersytetu Kazimierza Wielkiego, 2016, s. 198.
}

DOI: http://dx.doi.org/10.12775/PCh.2017.039

Zagadnienia dotyczące starości i starzenia się człowieka ${ }^{1}$ są coraz częściej przedmiotem zainteresowania przedstawicieli rozmaitych dyscyplin naukowych ${ }^{2}$. Przyczyną tego jest niewątpliwie wzrost populacji ludzi starszych

* Dr hab. Marek Marczewski, prof. WSSE, jest profesorem w Wyższej Szkole Społeczno-Ekonomicznej w Gdańsku. Adres: Wyższa Szkoła Społeczno-Ekonomiczna w Gdańsku, ul. Rajska 6,80-850 Gdańsk; e-mail: mamarcz@wp.pl.

${ }^{1}$ Por. Halina Worach-Kardas, Starość w cyklu życia. Spoleczne i zdrowotne oblicza późnej dorostości (Katowice: „Śląsk”, 2015), 15-36.

${ }^{2}$ Norbert Pikuła, Etos starości w aspekcie społecznym. Gerontologia dla pracowników socjalnych (Kraków: Wyższa Szkoła Filozoficzno-Pedagogiczna Ignatianum, Wydawnictwo WAM, 2011), 11. 
na świecie i związana „z tym wyłaniająca się potrzeba poprawy jakości ich życia, poprawy świadczeń społecznych, emerytalnych, opiekuńczych i zdrowotnych"”. Demograficzna starość stanowi więc ważną kwestię społecznąa ${ }^{4}$. Należy zauważyć, że późna dorosłość nie jest wolna od różnych zjawisk problemowych, których występowanie wymaga podejmowania działań o charakterze pomocowym i terapeutycznym ${ }^{5}$. Zalicza się do nich między innymi zachowania ryzykowne ${ }^{6}$. Problematyce tej została poświęcona książka Elżbiety Kościńskiej pod tytułem: Zachowania ryzykowne seniorów. Uwarunkowania, profilaktyka, opublikowana w 2016 roku nakładem Wydawnictwa Uniwersytetu Kazimierza Wielkiego w Bydgoszczy. Jej Autorka jest adiunktem w Zakładzie Pedagogiki Społecznej UKW. Ma na swoim koncie wiele publikacji naukowych poświęconych tematyce senioralnej ${ }^{7}$.

3 Stanisława Steuden, Psychologia starzenia się i starości (Warszawa: Wydawnictwo Naukowe PWN, 2014), 9.

${ }^{4}$ Małgorzata Halicka, Jerzy Halicki, Emilia Kramkowska, „Wprowadzenie”, w: Starość. Poznać, przeżyć, zrozumieć, red. Małgorzata Halicka, Jerzy Halicki, Emilia Kramkowska (Białystok: Wydawnictwo Uniwersytetu w Białymstoku, 2016), 13.

5 Joanna K. Wawrzyniak, Artur Fabiś, „Zachowania patologiczne w starości i wobec osób starszych", w: Artur Fabiś, Joanna K. Wawrzyniak, Agata Chabior, Ludzka starość. Wybrane zagadnienia gerontologii społecznej (Kraków: Oficyna Wydawnicza „Impuls”, 2015), 298.

6 Por. Marzena Binczycka-Anholcer, „Zachowania suicydalne osób w starszym wieku”, Suicydologia 1 (2005): 77-87; Małgorzata Suwała, Andrzej Gerstenkorn, „Palenie tytoniu i picie alkoholu w wielkomiejskiej populacji osób w starszym wieku”, Psychogeriatria Polska 4 (2006): 191-200; Małgorzata Suwała, Andrzej Gerstenkorn, „Rozpoznawanie problemów alkoholowych u osób w wieku powyżej 65 lat”, Gerontologia Polska 4 (2006): 172-178; Stanisława Tucholska, „Ryzyko zachowań samobójczych osób starszych”, w: Starzenie się a satysfakcja z życia, red. Stanisława Steuden, Mieczysław Marczuk (Lublin: Wydawnictwo KUL, 2006), 133-143; Elżbieta Kościńska, „Zachowania antyzdrowotne podejmowane przez seniorów”, Acta Pomerania 1 (2008): 203-211; Katarzyna Błaszczuk, Dorota Rynkowska, „Zdrowie seniorów wobec czynników ryzyka”, w: Historyczno-społeczne aspekty starzenia się i starości, red. Małgorzata Stawiak-Ososińska, Agnieszka Szplit (Kielce: Agencja Reklamowa TOP - Drukarnia Cyfrowa, 2014), 180-189.

7 Zob. Edukacja zdrowotna seniorów i osób przewlekle chorych (Bydgoszcz: Wydawnictwo Uniwersytetu Kazimierza Wielkiego, 2010); ,Rola rodziny w życiu człowieka starego w opiniach seniorów", w: Spoleczny wymiar życia i aktywności osób starszych, red. Aneta Baranowska, Elżbieta Kościńska, Katarzyna M. Wasilewska-Ostrowska (Toruń: Wydawnictwo Edukacyjne „AKAPIT”, 2013), 79-93; „Aktywność społeczna seniorów (z cukrzycą) w kontekście edukacji zdrowotnej”, Edukacja Ustawiczna Dorostych 2 (2016): 90-99; „Style życia seniorów chorych na cukrzycę”, Edukacja Dorostych 2 (2016): 59-70; „Kapitał społeczny seniorów jako źródło wsparcia rodziny”, Pedagogika Społeczna 1 (2017): 97-110. 
Jak Elżbieta Kościńska podała we „Wprowadzeniu”: „Praca dotyczy zachowań ryzykownych podejmowanych przez seniorów, ich rozpowszechnienia, uwarunkowań oraz profilaktyki stosowanej przez pracowników medycznych (lekarzy pierwszego kontaktu, pielęgniarek środowiskowych) i socjalnych, którzy niemal każdego dnia spotykają się ze swoim pacjentem/ podopiecznym" (s. 9). Przyjęła, że poznanie tego rodzaju zachowań wśród ludzi starszych oraz ich uwarunkowań jest konieczne do realizacji profilaktyki i edukacji zdrowotnej, a także promocji zdrowia (s. 10).

Książka składa się z siedmiu rozdziałów. W pierwszym Autorka dokonała rzetelnej, wieloaspektowej charakterystyki procesu starzenia się człowieka oraz okresu późnej dorosłości (s. 13-35). Uwzględniła dokonujące się zmiany demograficzne współczesnych społeczeństw i ich konsekwencje, omówiła etapy starości oraz zmiany biologiczne i psychiczne związane $\mathrm{z}$ procesem starzenia się, nie pominęła również - istotnych z punktu widzenia podjętej tematyki - problemów egzystencjalnych i zdrowotnych osób starszych. Mniej uwagi poświęciła natomiast koncepcji aktywnego starzenia się.

Rozdział drugi to niezwykle interesujący wykład na temat zachowań ryzykownych (s. 36-54). Autorka wyszła od ich zdefiniowania ${ }^{8}$, przytaczając i analizując stanowiska różnych badaczy. Przyjęła, ,że zachowania ryzykowne to takie zachowania, które mogą zdrowie niszczyć (uszkadzać), mogą zdrowiu zagrażać i (..) w różnym stopniu utrudniać proces zdrowienia" (s. 37). W dalszej kolejności omówiła wybrane rodzaje zachowań ryzykownych ludzi starszych oraz ich skutki zdrowotne. Ponadto w wyczerpujący sposób scharakteryzowała czynniki, jakie sprzyjają podejmowaniu tychże zachowań przez osoby w starszym wieku. Można przeczytać w tej części pracy między innymi, że ,zachowania ryzykowne są często społecznie akceptowane, czasami nawet podziwiane. Zachowania kształtowane kulturą środowiska mogą stanowić wzorce postępowania, które człowiek nabywa w trakcie swojego życia, i które wraz z czynnikami dziedzicznymi $\mathrm{i}$ indywidualnymi doświadczeniami kształtują wybory oraz zachowania jednostki" (s. 45).

W rozdziale trzecim Elżbieta Kościńska dokonała syntetycznego przeglądu ważniejszych teorii i modeli wyjaśniających podejmowanie zachowań ryzykownych, poświęcając najwięcej uwagi teorii dysonansu poznawczego i teorii własnej skuteczności (s. 55-62). W kolejnym natomiast omówiła

${ }^{8}$ Por. też: Kościńska, ,Zachowania antyzdrowotne”, 203. 
zachowania ryzykowne ludzi starszych (rozpatrywane jako problem zdrowia publicznego), odwołując się do wyników licznych badań (s. 63-72). Uwzględniła kolejno: palenie tytoniu, nadużywanie alkoholu, stosowanie leków bez zaleceń lekarzy oraz zachowania samobójcze.

Teoretyczną część pracy zamyka rozdział piąty, obejmujący kluczowe zagadnienia dotyczące profilaktyki zachowań ryzykownych (s. 73-88). Autorka - odwołując się do trafnie dobranej literatury naukowej - nie tylko wyjaśniła istotę profilaktyki oraz scharakteryzowała jej poziomy, obszary i strategie, ale także wskazała na rolę wybranych środowisk (rodzina, Kościól, personel medyczny, środki masowego przekazu) we wspieraniu profilaktyki zachowań ryzykownych ludzi w starszym wieku. Jak słusznie zauważyła: „Publiczna edukacja dotycząca problemów zachowań ryzykownych mogłaby zapobiec bardziej rozpowszechnionym i mniej poważnym zaburzeniom związanym z używaniem substancji, a udzielenie wskazówek odnoszących się do strategii samopomocowych przyczyniłoby się do tego, że w większości przypadków profesjonalna pomoc nie byłaby potrzebna. W tym celu można wykorzystać media” (s. 88).

Gruntowne analizy teoretyczne umożliwiły Elżbiecie Kościńskiej opracowanie i szczegółowe przedstawienie założeń metodologicznych badań własnych w rozdziale szóstym (s. 89-104). Sformułowała ona następujące problemy badawcze: Jaka jest częstość oraz wzorce zachowań ryzykownych wśród ludzi starszych?; Jaki występuje związek pomiędzy płcią, wiekiem, wykształceniem, miejscem zamieszkania, zamieszkiwaniem samotnym (lub niesamotnym), rodzajem zajmowanego lokalu, udziałem w zajęciach, stosunkiem do wiary, sytuacją materialną, oceną własnego zdrowia oraz satysfakcją życiową a częstością i wzorcami zachowań ryzykownych osób starszych?; W jaki sposób pracownicy medyczni i socjalni postrzegają problem zachowań ryzykownych wśród ludzi w starszym wieku?; Jakie czynności podejmują pracownicy socjalni i medyczni, mające na celu ograniczenie zachowań ryzykownych u osób starszych? Autorka scharakteryzowała również zmienne i wskaźniki. Omówiła ponadto sposób doboru osób badanych oraz organizację badań, a także dokonała charakterystyki społeczno-demograficznej respondentów. Badania zostały zrealizowane z zastosowaniem strategii ilościowej. Jako metodę badawczą umiejętnie wykorzystano sondaż diagnostyczny.

W rozdziale siódmym Elżbieta Kościńska poddała szczegółowej analizie wyniki przeprowadzonych badań (s. 105-158). Dotyczyły one w głównej mierze takich kwestii, jak: palenie tytoniu, spożywanie alkoholu, stosowanie leków bez zaleceń lekarzy oraz zachowania samobójcze (76,8\% badanych 
palących tytoń było nałogowymi palaczami; $37,5 \%$ respondentów pijących alkohol wykazywało ryzykowny wzór picia, a 17,6\% - stosowało alkohol w sposób szkodliwy dla zdrowia; $17,5 \%$ badanych przyjmujących leki bez zaleceń lekarzy zażywało je raz bądź kilka razy w tygodniu; niemal 24,4\% respondentów przejawiających zachowania samobójcze miało za sobą próbę lub próby samobójcze). Część rezultatów badań odnosiła się do opinii pracowników medycznych i socjalnych dotyczących rozpowszechnienia zachowań ryzykownych u osób starszych (oraz ich uwarunkowań), a także działań podejmowanych przez pracowników socjalnych i medycznych w ramach profilaktyki zachowań ryzykownych seniorów. Przeprowadzona analiza i interpretacja wyników badań skłoniła Autorkę do wyprowadzenia szeregu wniosków istotnych dla praktyki edukacyjnej. Szczególnie cenne są uwagi zawarte w końcowej części rozdziału (s. 157-158). Wskazano w niej między innymi na potrzebę rozwijania poradnictwa medycznego oraz szeroko rozumianego wsparcia społecznego dla osób starszych ${ }^{9} \mathrm{w}$ zakresie: eliminowania (bądź ograniczania) palenia tytoniu, ograniczania spożywania alkoholu oraz stosowania leków bez zaleceń lekarzy, a także eliminowania (lub ograniczania) zachowań samobójczych. Autorka podkreśliła rolę lekarza rodzinnego oraz pielęgniarki środowiskowej w sferze motywowania ludzi starszych do prowadzenia prozdrowotnego stylu życia. Jak ponadto stwierdziła: „Zadaniem pracownika socjalnego w aspekcie profilaktyki zachowań ryzykownych powinno być dążenie do zachowania aktywności osób starszych, zapobieganie osamotnieniu i izolacji społecznej poprzez promowanie odpowiedzialności za swoje zdrowie i pomoc w odnawianiu lub podtrzymywaniu i rozwijaniu kontaktów społecznych z rodziną, sąsiadami, szerszą społecznością. Nakłanianie do uczestnictwa w zajęciach proponowanych np. przez uniwersytety trzeciego wieku i/lub kluby seniora" (s. 158). Zwróciła więc uwagę na rolę pracy socjalnej we wspomaganiu rozwoju seniorów ${ }^{10}$, między innymi poprzez działania edukacyjne ${ }^{11}$. Trzeba w pełni zgodzić się ze stwierdzeniem Elżbiety Kościńskiej, że: „W realizacji działań profilak-

9 Por. Tomasz Różański, „Pomoc i wsparcie społeczne osób w wieku późnej dorosłości”, w: Rodzina wobec problemów i wyzwań wspótczesności. W poszukiwaniu rozwiązań, t. 2, red. Bożena Chrostowska, Magdalena Dymowska, Magdalena Zmysłowska (Olsztyn: Wydawnictwo Uniwersytetu Warmińsko-Mazurskiego, 2015), 290-292.

${ }^{10}$ Por. Anna Leszczyńska-Rejchert, Praca socjalna z seniorami w perspektywie geragogiki (Olsztyn: Wydawnictwo Uniwersytetu Warmińsko-Mazurskiego, 2016), 79-82.

${ }^{11}$ Por. Ewa Kantowicz, Pedagogika (w) pracy socjalnej (Olsztyn: Wydawnictwo Uniwersytetu Warmińsko-Mazurskiego, 2012), 122-124. 
tycznych oprócz profesjonalistów (pracownicy medyczni i socjalni) należy uwzględnić również: rodzinę, Kościół, a także środki masowego przekazu, jako potencjalne źródła wiedzy i możliwości aktywizacji seniorów. Profilaktyka zachowań ryzykownych (...) powinna mieć wieloaspektowy charakter. Dopiero połączenie różnych strategii profilaktycznych i działań instytucji wspierających może przynieść oczekiwane efekty" (s. 157).

Recenzowana książka ma przejrzystą strukturę i napisana jest przystępnym językiem. Zawiera liczne tabele $\mathrm{z}$ danymi oraz rysunki, które $\mathrm{w}$ znacznym stopniu ułatwiają jej lekturę, a także zamieszczone na końcu narzędzia badawcze i obszerny wykaz literatury. Publikacja obejmuje rozległą i uporządkowaną wiedzę dotyczącą okresu starości, w tym problemów egzystencjalnych i zdrowotnych osób starszych, a także zachowań ryzykownych seniorów oraz ich uwarunkowań i profilaktyki. Z uwagi na swój interdyscyplinarny charakter może posłużyć jako podręcznik dla słuchaczy różnych kierunków studiów. Warto polecić ją również badaczom, nauczycielom akademickim oraz specjalistom pracującym z ludźmi w starszym wieku.

Podsumowując, należy stwierdzić, że praca Elżbiety Kościńskiej stanowi ciekawe i starannie przygotowane studium teoretyczno-empiryczne podejmujące ważny problem badawczy. Książka skłania do refleksji nad kondycją współczesnych seniorów. Ponadto uświadamia potrzebę ciągłego doskonalenia i poszerzania oferty $\mathrm{w}$ zakresie profilaktyki i edukacji zdrowotnej.

Tomasz Różański*

\section{Bibliografia}

Binczycka-Anholcer, Marzena. „Zachowania suicydalne osób w starszym wieku”. Suicydologia 1 (2005): 77-87.

Błaszczuk, Katarzyna, Dorota Rynkowska. „Zdrowie seniorów wobec czynników ryzyka". W: Historyczno-spoleczne aspekty starzenia się i starości, red. Małgorzata Stawiak-Ososińska, Agnieszka Szplit, 180-189. Kielce: Agencja Reklamowa TOP - Drukarnia Cyfrowa, 2014.

* Dr Tomasz Różański jest adiunktem w Katedrze Socjologii Edukacji i Pedagogiki Społecznej na Wydziale Nauk Pedagogicznych Uniwersytetu Mikołaja Kopernika w Toruniu. Adres: Wydział Nauk Pedagogicznych UMK, ul. Lwowska 1, 87-100 Toruń; e-mail: tomrozan1@umk.pl. 
Halicka, Małgorzata, Jerzy Halicki, Emilia Kramkowska. „Wprowadzenie”. W: Starość. Poznać, przeżyć, zrozumieć, red. Małgorzata Halicka, Jerzy Halicki, Emilia Kramkowska, 13-14. Białystok: Wydawnictwo Uniwersytetu w Białymstoku, 2016.

Kantowicz, Ewa. Pedagogika (w) pracy socjalnej. Olsztyn: Wydawnictwo Uniwersytetu Warmińsko-Mazurskiego, 2012.

Kościńska, Elżbieta. „Aktywność społeczna seniorów (z cukrzycą), w kontekście edukacji zdrowotnej”. Edukacja Ustawiczna Dorostych 2 (2016): 90-99.

Kościńska, Elżbieta. „Kapitał społeczny seniorów jako źródło wsparcia rodziny”. Pedagogika Spoleczna 1 (2017): 97-110.

Kościńska, Elżbieta. „Rola rodziny w życiu człowieka starego w opiniach seniorów”. W: Społeczny wymiar życia i aktywności osób starszych, red. Aneta Baranowska, Elżbieta Kościńska, Katarzyna M. Wasilewska-Ostrowska, 79-93. Torun: Wydawnictwo Edukacyjne „AKAPIT”, 2013.

Kościńska, Elżbieta. „Style życia seniorów chorych na cukrzycę”. Edukacja Dorostych 2 (2016): 59-70.

Kościńska, Elżbieta. „Zachowania antyzdrowotne podejmowane przez seniorów”. Acta Pomerania 1 (2008): 203-211.

Kościńska, Elżbieta. Edukacja zdrowotna seniorów i osób przewlekle chorych. Bydgoszcz: Wydawnictwo Uniwersytetu Kazimierza Wielkiego, 2010.

Kościńska, Elżbieta. Zachowania ryzykowne seniorów. Uwarunkowania, profilaktyka. Bydgoszcz: Wydawnictwo Uniwersytetu Kazimierza Wielkiego, 2016.

Leszczyńska-Rejchert, Anna. Praca socjalna z seniorami w perspektywie geragogiki. Olsztyn: Wydawnictwo Uniwersytetu Warmińsko-Mazurskiego, 2016.

Pikuła, Norbert. Etos starości w aspekcie społecznym. Gerontologia dla pracowników socjalnych. Kraków: Wyższa Szkoła Filozoficzno-Pedagogiczna Ignatianum, Wydawnictwo WAM, 2011.

Różański, Tomasz. „Pomoc i wsparcie społeczne osób w wieku późnej dorosłości”. W: Rodzina wobec problemów i wyzwań wspótczesności. W poszukiwaniu rozwiąań, t. 2, red. Bożena Chrostowska, Magdalena Dymowska, Magdalena Zmysłowska, 285-294. Olsztyn: Wydawnictwo Uniwersytetu Warmińsko-Mazurskiego, 2015.

Steuden, Stanisława. Psychologia starzenia się i starości. Warszawa: Wydawnictwo Naukowe PWN, 2014.

Suwała, Małgorzata, Andrzej Gerstenkorn. „Palenie tytoniu i picie alkoholu w wielkomiejskiej populacji osób w starszym wieku". Psychogeriatria Polska 4 (2006): 191-200.

Suwała, Małgorzata, Andrzej Gerstenkorn. „Rozpoznawanie problemów alkoholowych u osób w wieku powyżej 65 lat”. Gerontologia Polska 4 (2006): 172-178. 
Tucholska, Stanisława. „Ryzyko zachowań samobójczych osób starszych”. W: Starzenie się a satysfakcja z życia, red. Stanisława Steuden, Mieczysław Marczuk, 133-143. Lublin: Wydawnictwo KUL, 2006.

Wawrzyniak, Joanna K., Artur Fabiś. ,Zachowania patologiczne w starości i wobec osób starszych". W: Artur Fabiś, Joanna K. Wawrzyniak, Agata Chabior, Ludzka starość. Wybrane zagadnienia gerontologii spotecznej, 298-329. Kraków: Oficyna Wydawnicza „Impuls”, 2015.

Worach-Kardas, Halina. Starość w cyklu życia. Spoleczne i zdrowotne oblicza późnej dorostości. Katowice: „Śląsk”, 2015. 